\title{
Bioaccumulation of Selected Metals in Fresh Water Haruan Fish (Channa striatus) Collected from Pahang River Basin, Malaysia
}

\author{
K.C.A. JALAL ${ }^{1,2}$, B. AKBAR JOHN ${ }^{1,2}$, M. HABAB ${ }^{2}$, \\ A.Y. MOHD ${ }^{2}$ and B.Y. KAMARUZZAMAN ${ }^{1,2 *}$ \\ ${ }^{1}$ Institute of Oceanography and Maritime studies (INOCEM), \\ ${ }^{2}$ Kulliyyah of Science, International Islamic University Malaysia. \\ Jalan Sultan Ahmad Shah, Bandar Indera Mahkota, 25200, Kuantan Pahang, Malaysia. \\ ${ }^{*}$ Corresponding author: kama@iium.edu.my \\ http://dx.doi.org/10.13005/ojc/290436
}

(Received: October 30, 2013; Accepted: December 02, 2013)

\begin{abstract}
A study on Copper $(\mathrm{Cu})$, Zinc $(\mathrm{Zn})$ and Lead $(\mathrm{Pb})$ concentration in fresh water fish Channastriatus -Haruan fish in Pahang, Malaysia was conducted. Three types of fish organs were studied. The organs were; liver, muscle and intestine. They were dissected and dried before the digestion process using $\mathrm{HNO}_{3}, \mathrm{H}_{2} \mathrm{SO}_{4}, \mathrm{H}_{2} \mathrm{O}_{2}$ and $\mathrm{HCL}$. Inductively Coupled Plasma Spectrometry (ICP-MS) was used for the detection of heavy metals. There was a significant variation in the concentration of zinc was observed between tissues of the studied fish $(P<0.05)$ while copper and lead showed no significant difference in accumulation between selected tissues. Nevertheless, the findings from this study revealed that all the heavy metals concentrations in the tissues were lower than the maximum permissible limit as recommended by The Malaysian Food Regulation and hence safe for human consumption. Long term monitoring study is needed to implement various fishery management plans to safeguard the quality of $C$. striatuswild stock.
\end{abstract}

Key words: Heavy metals ;Channastriatus; Pahang river, Bioaccumulation.

\section{INTRODUCTION}

Heavy metals are natural components of the earth's crust that cannot be degraded or destroyed. They are metallic elements that have a relatively high density, toxic and poisonous. According to many researchers (Blaber, (2000; Farombi, et al., 2007; Ashraj, 2005; Brewer, 2010), heavy metals can cause contaminations that result in a long lasting effect on the ecological balance of the environment and the diversity of the different aquatic species living in it. Mansour and Sidky (2002) stated that, among the aquatic species, fishes are the mostly endangered as they cannot escape from the effects of these pollutants. They can accumulate large amounts of heavy metals from the waters inside their body. Fishes are an essential source of nutrition, they are high in protein and a great source of omega-3 fatty 
acids, vitamins and can reduce the risk of various diseases such as heart attacks, strokes, diabetes, Alzheimer's disease and sudden death. Although the consumption of fish can benefit its consumers and shape up their health, it can also raise some health concerns as it can be contaminated with toxic metals from the pollution of their aquatic environment (Kennish, 2001; Madhusudan et al., 2003; Kojadinovic et al., 2006). Despite the fact that most heavy metals such as mercury, cadmium and lead are toxic and dangerous, there are some heavy metals that are essential and must be taken in small quantities such as iron, copper, manganese and zinc (Vosyliene and Jankaite, 2006; Mohammad and Hossam, 2007; RinaSharlindaZabri, 2009).

Heavy metals accumulate in the tissues of marine organisms and fishes can easily absorb those heavy metals from the waters, and by measuring the levels of heavy metals accumulation; previous exposures can be known (Basa et al., 2003; Ashraf, 2005). Even though there is a noticeable concentration on pollutions caused by heavy metals, there is still a shortage of data and researches on the accumulation of heavy metals in fresh waters commercial fish species in Malaysia.

Haruan is also known as snakehead fish belongs to the family Channidae. Haruan is available throughout the year in Malaysia. Due to its popularity and increasing consumption in Malaysia, there is an urgent need to know the existing status of heavy metals in the different organs of this fish and to know whether it is alarming to consume in the future. Thus, this research was conducted to determine the accumulation of selected metals such as copper, zinc and lead in one of fresh waters species (Channa striatus - Haruan fish) for this study.

\section{MATERIALS AND METHODS}

\section{Sample collection and preparation}

The fish samples $(\mathrm{N}=158)$ were collected from local fish market where the fish are caught from fresh waters areas in Pahang. The collected fishes were then placed in an icebox. After that they were transported to the laboratory and kept in at $-20{ }^{\circ} \mathrm{C}$ freezer before further analysis.Firstly, all the fish samples were thawed to room temperatures after being excelled from the freezer. Then, they were rinsed with distilled water to remove sands and debris possibly trapped in its organs. At the same time, acidwashed Petri dishes were prepared with labels before the dissection process took place. The liver, muscle and intestine of each fish were excised using sterile scissors and forceps and cleaned running tape water and then with sterile distilled water. The dissected parts were placed in the Petri dishes for drying purposes in the oven at $60^{\circ} \mathrm{C}$ for a week period. After the drying period, the samples were inspected for any moisture in accordance to the procedures described by (Rina, 2009. The samples were then kept in acid-rinsed containers for determining its constant weights.

\section{Heavy metal analysis \\ Open Digestion Method}

Sample preparation and analysis were carried out according to the procedure described by (Kamaruzzaman et al., 2011). Samples for heavy metal analysis (including SRM and blank) were digested in Teflon beakers containing $10 \mathrm{ml}$ of concentrated $\mathrm{HNO}_{3}, 2 \mathrm{ml}$ of concentrated $\mathrm{H}_{2} \mathrm{SO}_{4}, 3 \mathrm{ml}$ of $\mathrm{H}_{2} \mathrm{O}_{2}$ and $2 \mathrm{ml}$ of $\mathrm{HCL}$ on the hot plate at $60{ }^{\circ} \mathrm{C}$ for about two hours to ensure complete digestion of all organic matters. When the digestion was completed, the solutions were left to cool down in ambient temperature. After cooling down, the digest were transferred into falcon tubes and were double washed with ultrapure water to ensure that the entire digest were transferred into the tube. The digest were made up to $50 \mathrm{ml}$ by adding $\mathrm{HNO}_{3}(5 \%)$. Clear solutions with no residues were obtained at this stage for samples as well as the blank and SRM. The digestion composition was then analyzed using a multi-element technique known as Inductively Coupled Plasmamass Spectrometry (ICP-MS)

\section{Data analysis}

Calculation of Metal Content $(\mu \mathrm{g} / \mathrm{g}$ dry weight) was carried out using following formula

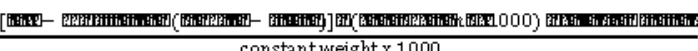
constantweight $x 1000$

and the Percentage Recovery was calculated using standard formula. One - way ANOVA was used to analyze the data obtained as it has the ability to test the quality of three or more means at one time by using variances. Analysis of Variance test was performed to determine the significant variation in the metal accumulation between the tissue samples. 


\section{RESULTS AND DISCUSSION}

The results of calibration standards showed coefficient correlation $(R)$ values greater than 0.995 which showed that the ICP-MS could produce acceptable data of the metals detected.

In addition, the percentage recovery values for the Standard Reference Material (SRM) which is oyster tissue 1566b were obtained in accordance to the heavy metals studied in this research. The values are well within the range of $96 \%$ to $104 \%$ (Table $1)$.

\section{Copper (Cu) Concentration in Fish Organs \\ The concentration of copper observed} in different parts of the fish is shown in Figure 1. The concentration of copper in different organs of the fish showed no significant variation ( $p>0.05$ ).
However, the observed copper concentration was higher in liver followed by muscle and intestine. Similar studies on other fresh water fish species conducted by (Alweher, 2008) showed significant difference in the accumulation of heavy metals in fish. The difference in findings can be due to the variation in the environment where the fish lives in, where several crucial factors such as temperature,

Table 1: Percentage Recovery of SRM 1566b Oyster Tissue

\begin{tabular}{llll}
\hline Metal & \multicolumn{3}{c}{ SRM 1566b Oyster Tissue } \\
\cline { 2 - 4 } & $\begin{array}{l}\text { Analyzed } \\
\text { Value }\end{array}$ & $\begin{array}{l}\text { Certified } \\
\text { Value }\end{array}$ & $\begin{array}{l}\text { Recovery } \\
(\%)\end{array}$ \\
\hline $\mathrm{Cu}$ & 70.00 & $71.6 \pm 1.6$ & $97.77 \%$ \\
$\mathrm{Zn}$ & 1480.00 & $1424 \pm 46$ & $103.93 \%$ \\
$\mathrm{~Pb}$ & 2.60 & $0.308 \pm 0.009$ & $104.84 \%$ \\
\hline
\end{tabular}

Table 2: ANOVA results of heavy metals in Channastriatus organs

\begin{tabular}{lllllll}
\hline \multirow{2}{*}{ Liver } & & $\begin{array}{l}\text { Sum of } \\
\text { Squares }\end{array}$ & df & Mean Square & F & Sig. \\
& Between Groups & 111.558 & 2 & 55.779 & 3.415 & .060 \\
& Within Groups & 245.021 & 15 & 16.335 & & \\
\multirow{3}{*}{ Muscle } & Total & 356.579 & 17 & & \multirow{2}{*}{308} \\
& Between Groups & 16.587 & 2 & 8.294 & & \\
& Within Groups & 97.530 & 15 & 6.502 & & \\
& Total & 114.118 & 17 & & & \\
& Between Groups & 8.989 & 2 & 4.495 & & \\
& Within Groups & 56.986 & 15 & 3.799 & & \\
& Total & 65.976 & 17 & & & \\
\hline
\end{tabular}

Table 3: Maximum permitted levels in fish enforced by Malaysia

\begin{tabular}{llcc}
\hline \multirow{2}{*}{ Country } & \multicolumn{3}{c}{ Concentration $(\mu \mathrm{g} / \mathbf{g ~ d w})$} \\
\cline { 2 - 4 } & $\mathbf{C u}$ & $\mathbf{Z n}$ & $\mathbf{P b}$ \\
\hline Malaysian Food & & & \\
Regulation (1985) & 30 & 100 & 2 \\
Present study & & & 0.031 \\
Liver & 5.843 & 4.535 & \\
Muscle & 2.237 & 1.824 & 0.012 \\
Intestine & 1.731 & 1.201 & 0.039 \\
\hline
\end{tabular}

salinity, habitats can affect the accumulation of heavy metals. It might also be due to detoxifying ability of liver that tend to accumulate compartitively large amount of copper in liver tissue.

\section{Zinc (Zn) Concentration in Fish Organs}

The concentration of zinc observed in different parts of the fish is shown in figure 2 .. Significant difference in $\mathrm{Zn}$ accumulation was observed between organs $(p<0.05)$. Similarly Yilmaz, (2009) stated that the liver had higher concentration of zinc compared with muscle in Orechoromisniloticus, Anquillaanquilla and Mugilcephalus. This was due to the fact that the liver 


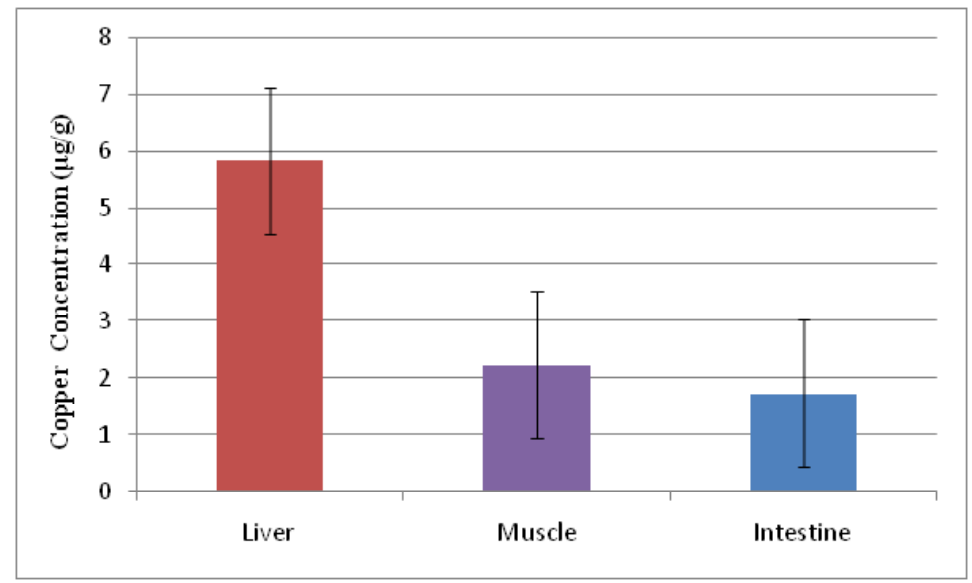

Fig. 1: Copper content in liver, muscle and intestine in Channastriatus - Haruan Fish. Bar with no letter are not significantly different $(p<0.05)$. Data are mean \pm standard deviation

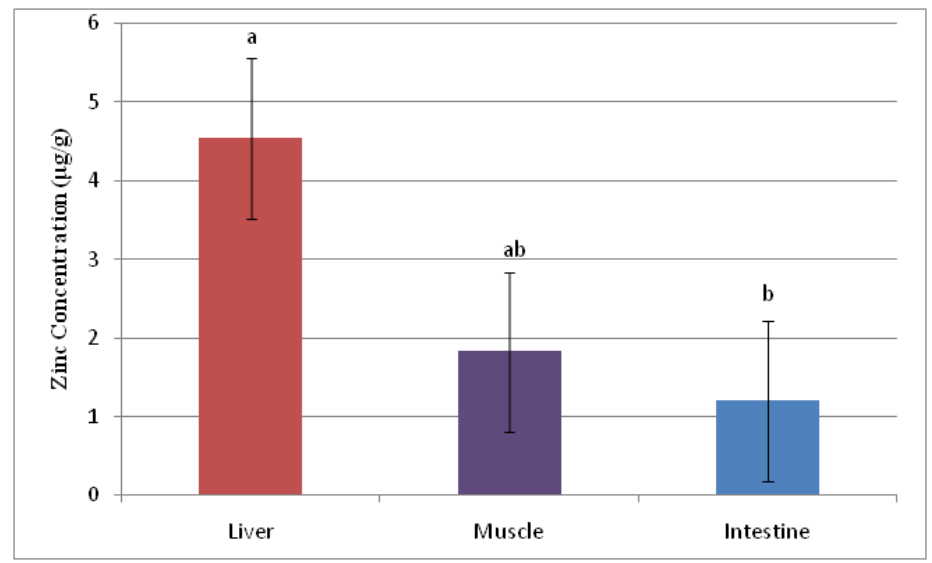

Fig. 2: Zinc content in liver, muscle and intestine in ChannastriatusHaruan fish. Bar with no letter in common are significantly different $(p<0.05)$. Data are mean \pm standard deviation

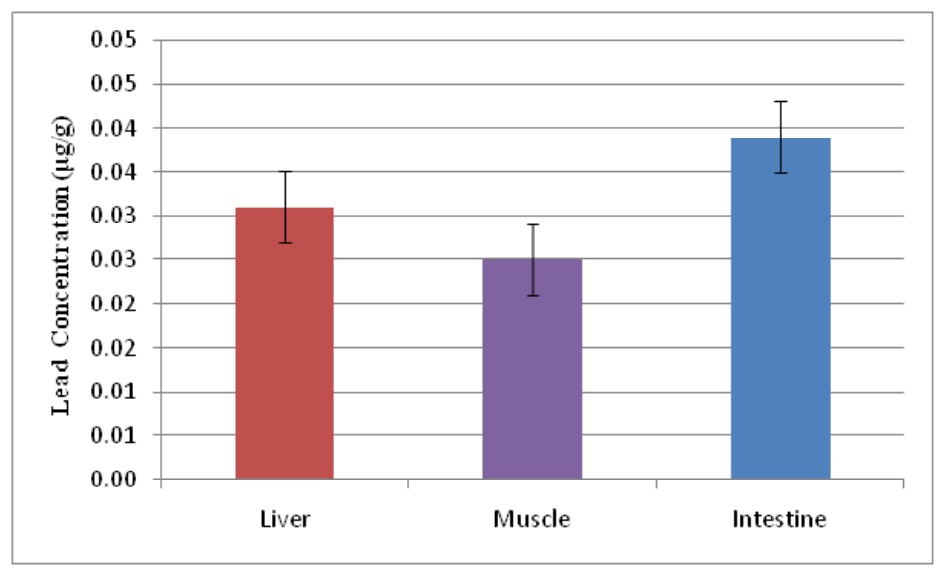

Fig. 3: Lead content in liver, muscle and intestine in ChannastriatusHaruan fish. Bar with no letter are not significantly different $(p<0.05)$. Data are mean \pm standard deviation 
is a target organ that accumulates a large amount of heavy metals because of its strong irrigation and extraction function. According to Yilmaz (2009), livers can also be indicators of the degree of pollution in the ecosystem. Meanwhile, muscle and intestine showed lower values of zinc because they are not active tissues in accumulating heavy metals.

\section{Lead $(\mathrm{Pb})$ Concentration in Fish Organs}

The concentration of lead observed in different parts of the fish is shown in figure 3 . No significant difference in $\mathrm{Pb}$ accumulation was observed between organs ( $p>0.05$ ). However, the related study by Vinodhini and Narayanan (2008) showed that there was significant difference of lead in liver and muscle in Cyprinuscarpio with a value. The variation between the findings might be due to the different types of species that were studied that have different ability in accumulating the lead. Another study conducted by Yilmaz (2009) showed variation in lead mean values in organs of different species which wereOrechoromisniloticus, Anquillaanquilla and Mugilcephalus.
Comparison of heavy metals showed no significant difference in the liver, muscle and intestine of Channastriatus (Table 2). The results obtained are similar with the (Al-Weher, 2008) findings which showed that no significant difference in muscles between copper and zinc in Oreochromisaureus, $C y$ prinuscarpioandClariaslazera. The results obtained are low and well within the permissible limit that is stated by The Malaysian Food Regulation 1985 that is shown in Table 3. The results of the present study indicate no evidence of noticeable pollution of the fish from Pahang, Malaysia.

\section{CONCLUSION}

In conclusion, Copper and lead accumulation in selected organs were not significantly different while Zink showed significant difference in bioaccumulation between organs $(P<0.05)$. The results obtained has clearly showed that the existing concentration of heavy metals in different tissues of Channastriatusis lower than national maximum permissible limits and hence safe for consumption.

\section{REFERENCES}

1. Alweher, S. M., Levels of heavy metals Cd, $\mathrm{Cu}$ and $\mathrm{Zn}$ in three fish species collected from the Northern Jordan Valley, Jordan. Jordan Journal of Biological Sciences 1(1):41-46 (2008).

2. Ashraf, W., Accumulation of heavy metals in kidney and heart tissues of Epinephelus microdon fish from the Arabian Gulf. Environ. Monit. Assess. 101: 311 (2005).

3. Ashraj, W., Accumulation of heavy metals in kidney and heart tissues of Pinephelusmicrodon fish from the Arabian Gulf. Environ. Monit.Assess., 101(1-3): 311316 (2005).

4. Basa, Siraj, P., Usha Rani, A., Cadmium induced antioxidant defense mechanism in freshwater teleost Oreochromismossambicus (Tilapia). Eco.Toxicol. Environ. Saf., 56(2): 218 -221 (2003).

5. Blaber, S.J.M., Tropical Estuarine Fishes: Ecology, Exploitation and Conservation.

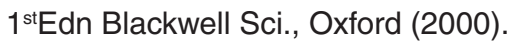

6. Brewer, G. J., Copper toxicity in the general population.Clin Neurophysiol. 121(4): 459-60 (2010).

7. Farombi, E. O., Adelowo, O. A. and Ajimoko, Y. R., Biomarkers of oxidative stress and heavy metal levels as indicators of environmental pollution in African Cat fish (Clariasgariepinus) from Nigeria ogun river. Int. J. Environ. Res. Public Health., 4(2): 158-165 (2007).

8. Kamaruzzaman,Y., Rina, Z., Akbar, J.B. and Jalal, K.C.A., Heavy Metals Accumulation in Commercially Important Fishes of SouthWest Malaysian Coast. Research Journal of Environmental Sciences. 5(6): 595-602 (2011).

9. Kennish, M. J., Coastal Salt Marsh Systems in the U.S.: A Review of Anthropogenic Impacts. Journal of Coastal Research 17(3): 731-748 (2001).

10. Kojadinovic J, Potier M, Le Corre M. Mercury content in commercial pelagic fish and its risk assessment in the Western Indian Ocean.Sci 
Total Environ 366: 688-700 (2006).

11. Madhusudan, S., Fatima, L. and Nadim, C. Bioaccumulation of zinc and cadmium in freshwater fishes. Indian J. Fish., 50(1): 53-65 (2003).

12. Mansour, S.A. and M.M. Sidky, Ecotoxicological studies. 3: Heavy metals contaminating water and fish from Fayoum Governorate, Egypt. Food Chem., 78: 15-22 (2002).

13. Mohammad, H.N.A.andHossam, H.H.A. Accumulation and distribution of copper and zinc in both water and some vital tissues of two fish species (Tilapia zilli and Mugilcephalus) of lake Qarun, Fayoum Province, Egypt, Pak, J. Biol.Sc. 10: 2106-2122 (2007).

14. Rina Sharlinda Zabri., Accumulation of Selected Heavy Metals ( $\mathrm{Zn}, \mathrm{Pb}$, As and $\mathrm{Hg}$ ) In
Some Marine Fishes from Straits of Malacca, Malaysia. Master Thesis. International Islamic University Malaysia (2009).

15. Vinodhini, R., and Narayanan, M. Bioaccumulation of heavy metals in organs of freshwater fish Cyprinuscarpio (common carp). Zoology. 5(2): 179-182 (2008).

16. Vosyliene, M. Z. and Jankaite, A., Effect of heavy metal model mixture on rainbow trout biological parameters.Ekologija., 4: 12-17 (2006).

17. Yilmaz, A.B., The comparison of heavy metal concentrations ( $\mathrm{Cd}, \mathrm{Cu}, \mathrm{Mn}, \mathrm{Pb}$ and $\mathrm{Zn}$ ) in Tissues of three economically important fish inhabiting Koycegiz Lake-Mugla, Turkey. Turkish Journal of Science and Technology. 4(1): 7 (2009). 